\title{
PENGEMBANGAN APLIKASI DAN WEBSITE MANAJEMEN PROYEK PT SANTAI BERKUALITAS SYBERINDO MENGGUNAKAN METODE AGILE
}

\section{PT. SANTAI BERKUALITAS SYBERINDO PROJECT MANAGEMENT APPLICATION AND WEBSITE DEVELOPMENT WITH AGILE METHOD}

\author{
Muhammad Shidqi ${ }^{1}$, Muhammad Amin Riqky ${ }^{2}$ \\ ${ }^{1}$ UIN Raden Fatah Palembang, Jl. Prof. K. H. Zainal Abidin Fikri, Palembang \\ ${ }^{2}$ UIN Raden Fatah Palembang, Jl. Prof. K. H. Zainal Abidin Fikri, Palembang \\ *E-mail: m.shidqi810@gmail.com
}

\begin{abstract}
ABSTRAK
PENGEMBANGAN APLIKASI DAN WEBSITE MANAJEMEN PROYEK PT SANTAI BERKUALITAS SYBERINDO MENGGUNAKAN METODE AGILE merupakan judul yang diangkat dalam penelitian ini, hal ini sangat berkaitan dengan PT. Santai Berkualitas Syberindo yang merupakan sebuah perusahaan yang bergerak di bidang teknologi. PT Santai Berkualitas Syberindo memiliki komitmen untuk membantu pekerjaan pelanggan menjadi lebih mudah melalui teknologi berbasis Web dan Mobile Apps. Namun dalam proses pengembangan tersebut ada permasalahan dalam memanajemen proyek yang sedang berlangsung ataupun yang telah selesai. Proyek yang sedang berjalan harus memiliki data yang jelas, dan lengkap. Hal ini tidak dapat dilakukan jika proyek yang sedang dikerjakan dan yang telah selesai tidak di arsipkan dengan baik. Oleh karena itulah diperlukannya sistem yang dapat memanajemen proyek proyek yang sedang berjalan tersebut. Sistem manajemen proyek tersebut dikembangkan menggunakan metode Agile yang berbasis Website serta Mobile Apps. Metode Agile digunakan dalam proses pengembangan karena metode ini dapat menyesuaikan dengan kebutuhan pengguna dan dapat dilakukan pengembangan secara berulang - ulang. Karena kebutuhan yang terdapat dalam pengembangan suatu proyek dapat bertambah suatu saat berdasarkan keadaan dan situasi yang ada. Framework yang digunakan dalam proses pengembangan Aplikasi dan Website manajemen proyek ini adalah Laravel dan React Native. Dengan adanya Website serta Aplikasi manajemen proyek ini diharapkan dapat membantu PT. Santai Berkualitas Syberindo dalam mengembangkan proyek yang mereka miliki.
\end{abstract}

Kata kunci: Aplikasi, Website, Manajemen Proyek, Agile, React Native, Laravel.

\begin{abstract}
PT. SANTAI BERKUALITAS SYBERINDO PROJECT MANAGEMENT APPLICATION AND WEBSITE DEVELOPMENT WITH AGILE METHOD is the title in this research, it is related to PT. PT. Santai Berkualitas Syberindo which is a company engaged in technology. PT Santai Berkualitas Syberindo is committed to helping customers work easier through Web-based technology and Mobile Apps. However, in the development process there are problems in managing ongoing or completed projects. Projects must have detailed data. This cannot be done if the projects are not properly archived. Therefore, we need a system that can manage these projects. This project management system was developed using the Agile method based on the Website and Mobile Apps. Agile methods are used in the development process because this method can adapt to user needs and can be developed repeatedly. Because the needs contained in the development of a project can increase at any time based on the situation. The frameworks used in this project management application and website development process are React Native and Laravel. With this website and project management application, it is hoped that it can helpPT Santai Berkualitas Syberindo in developing the projects they have.
\end{abstract}

Keywords: Application, Website, Project Management, Agile, React Native, Laravel. 


\section{PENDAHULUAN}

Aplikasi dan website merupakan beberapa contoh dari teknologi yang sangat membantu manusia dalam mengerjakan beberapa pekerjaannya. Sifat nya yang dinamis, mudah di akses, tersedia setiap saat, dan memiliki kekuatan untuk memenuhi kebutuhan manusia lah yang membuat aplikasi dan website tersebut sangat diminati oleh banyak orang [1].

Proyek pengembangan aplikasi atau website kini semakin banyak yang harus dipenuhi. Hal ini terjadi dikarenakan semakin berkembangnya jaman serta teknologi yang ada, hal ini mengakibatkan berbagai sektor bidang ingin menggunakan teknologi untuk membantu operasional maupun kegiatan lainnya. Teknologi tersebut akan membantu mereka mengerjakan berbagai macam kegiatan menjadi lebih mudah dan efisien [2].

Untuk dapat menyelesaikan proyek yang ada sesuai dengan kesepakatan serta waktu yang ada, harus disertai dengan perencanaan serta implementasi yang matang dan relevan dengan permintaan dari proyek tersebut. Kegiatan membuat perancanaan serta impelentasi yang matang dan relevan itulah yang disebut sebagai manajemen proyek [3]. Jika tidak ada manajemen proyek dalam proses pengembangannya maka perencanaan, pelaksanaan, pengendalian, dan koordinasi suatu proyek akan sulit untuk dilakukan, dan hal ini dapat mengakibatkan terjadinya proyek yang tidak tepat waktu, tidak tepat biaya, dan tidak tepat mutu.

Berdasarkan pengamatan yang penulis lakukan, PT Santai Berkualitas Syberindo merupakan salah satu pengembang proyek aplikasi dan website yang baik. Namun mereka belum memiliki sebuah sistem yang dapat memanajemen proyek yang sedang mereka kerjakan ataupun yang telah selesai. Oleh karena itulah sistem ini diharapkan dapat membantu PT Santai Berkualitas Syberindo dalam memanajemen proyek yang mereka memiliki.

\section{METODOLOGI}

1. Metode Pengembangan Perangkat Lunak

Agile merupakan metodologi yang memiliki adaptibilitas tinggi untuk menghadapi perubahan yang akan terjadi pada setiap elemennya. Metode ini memecah sebuah proyek besar menjadi bagian bagian kecil yang akan di kerjakan secara berkala kepada pengguna. Proses ini disebut sebagai iterasi atau sprint. Cara ini dapat meningkatkan kepuasan pengguna terhadap hasil dari proyek tersebut dikarenakan pengguna dilibatkan secara langsung dan di dengarkan pendapatnya terhadap proyek tersebut [4].

Dalam proses pengerjaan proyek, metode Agile memiliki 5 tahapan yang harus dilakukan, tahapan tersebut dibantu dengan sebuah kerangka kerja yang Bernama Scrum. 5 tahapan itu meliputi [5]:

a. Product Backlog

Tahap ini merupakan proses pengumpulan data dan informasi mengenai kebutuhan dari proyek yang sedang berjalan. Proses pengumpulan data ini dilakukan dengan cara wawancara dan observasi.

b. Sprint Backlog

Tahap ini membagi proses proses yang diperlukan menjadi beberapa bagian yang nantinya akan dikerjakan pada fase sprint. Durasi dari tahap pengerjaannya disepakati berdasakan diskusi bersama.

c. Sprint Planning

Tahap ini merupakan proses membuat perencanaan dalam proses pengerjaan product backlog pada sprint. Tahap ini biasanya terdiri dari proses pembuatan rancangan alur sistem serta rancangan basis data yang akan dibuat dan digunakan. Pada tahap Sprint Planning ini juga lah membuat estimasi dari pengerjaan Sprint.

d. Sprint

Sprint merupakan unit kerja yang digunakan untuk memenuhi kebutuhan yang telah ada pada Backlog. Proses pengerjaan ditentukan berdasarkan waktu yang telah disepakati oleh tim sebelumnya. Pada tahap sprint ini terdapat beberapa proses yang terdiri dari Proses To Do, Testing, Revision jika ada, dan Complete.

e. Review dan Retrosprective

Setelah fase Sprint telah diselesaikan, sistem akan dilakukan pengujian yang bertujuan untuk mencari kekurangan yang terdapat di dalam sistem. Pada tahap ini juga akan mencari tahu apakah ada feedback atau masukan atas sistem yang telah dilakukan pengujian.

2. Teknik Pengumpulan Data

a. Wawancara

Penulis melakukan wawancara lansung dan tanya jawab dengan pihak-pihak yang terlibat. 
b. Observasi

Penulis langsung melakukan pengamatan terhadap kegiatan yang berhubungan dengan masalah yang diambil, agar memperoleh data dan keterangan yang lebih lengkap.

3. Teknik yang digunakan dalam proses pengembangan

Laravel merupakan framework pengembangan website yang menggunakan bahasa PHP. Framework ini digunakan dalam penelitian dikarenakan sifatnya yang kontemporer, open source dan digunakan secara luas untuk perancangan aplikasi web yang cepat dan mudah. Framework ini dibuat untuk pengembangan aplikasi website dimana mengikuti arsitektur MVC (model view controller). Laravel merupakan developments tool framework yang cocok digunakan dalam penelitian ini karena Laravel memiliki waktu eksekusi yang sedikit sehingga website memiliki proses loading yang cepat [6].

\section{HASIL DAN PEMBAHASAN}

\section{Tahap Pembuatan Sprint}

Dalam proses penelitian serta pengembangan yang dilakukan penulis. Akan dijelaskan berdasarkan tahapan yang terdapat pada agile. Proses tersebut dimulai dengan menyusun Product Backlog yang didapatkan melalui proses wawancara serta observasi yang dilakukan oleh penulis.

Tabel 1. Backlog Item

\begin{tabular}{cl}
\hline No. & Backlog Item \\
\hline 1. & Login menggunakan 2 hak akses \\
2. & Admin mengolah data dari \\
& datamaster \\
& Admin dapat melihat ringkasan \\
3. & seluruh data yang terdapat di sistem \\
melalui halaman Dashboard \\
Klien dapat melihat ringkasan data \\
4. dari proyek miliknya melalui \\
halaman Dashboard \\
5. Admin mengolah seluruh data di \\
sub menu proyek \\
6. $\quad$ Klien mengolah data dari proyek
\end{tabular}

Admin mengolah data seluruh

7. Billing atau pembayaran dari proyek yang ada

8.

Klien mengolah data Billing dari

proyek miliknya

Admin mengolah seluruh data akun

9. yang terdaftar di dalam sistem

Klien mengolah data dari akun

10. miliknya yang terdaftar di dalam sistem

Admin dapat melihat ringkasan

11. seluruh data yang terdapat di sistem

melalui halaman Dashboard

Klien dapat melihat ringkasan data

12. dari proyek miliknya melalui

halaman Dashboard

Langkah kedua adalah Sprint Backlog, pada tahap ini penulis membagi Product Backlog menjadi beberapa bagian yang lebih detail. Lalu Backlog Item tersebut akan diurutkan berdasarkan prioritasnya, lalu akan disertakan dengan estimasi dari pengerjaannya yaitu dengan membuat daftar product backlog item yang terpilih dan terurut berdasarkan prioritasnya untuk dikerjakan dalam sprint dengan perencanaan dan perkiraan mengenai fungsionalitasnya untuk menghasilkan produk yang diinginkan [7]. Berikut ini adalah table dari Sprint Backlog.

Tabel 2. Sprint Backlog

\begin{tabular}{llc}
\hline No. & Pekerjaan & $\begin{array}{c}\text { Estimasi } \\
\text { (Hari) }\end{array}$ \\
\hline 1. & $\begin{array}{l}\text { Membuat tampilan } \\
\text { menu } \\
\text { Membedakan antara }\end{array}$ \\
hak akses yang \\
dimiliki oleh admin \\
dan Klien \\
Membuat halaman \\
3. Dashboard
\end{tabular}


Membuat halaman

4. Riwayat

Membuat halaman

5. logbook proyek

Membuat halaman

6. Domain proyek

Membuat halaman

7. Hosting proyek

8. Membuat halaman

8. Dokumen proyek

9. Membuat halaman

Maintenance

10.

Membuat halaman

Billing proyek

11.

Membuat halaman

Data Master

12.

Membuat halaman

data akun

Langkah yang ketiga adalah membuat Sprint Planning. Sprint Planning ini terdiri dari alur kerja sistem (flowchart) serta rancangan dari basis data yang dibutuhkan.

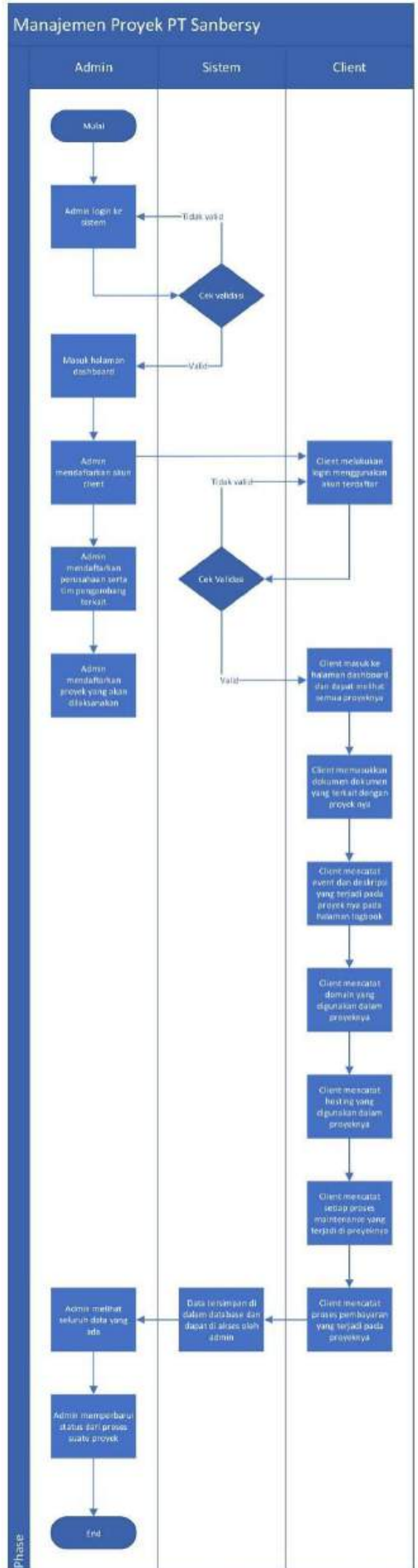

Gambar 1. Flowchart Sistem 


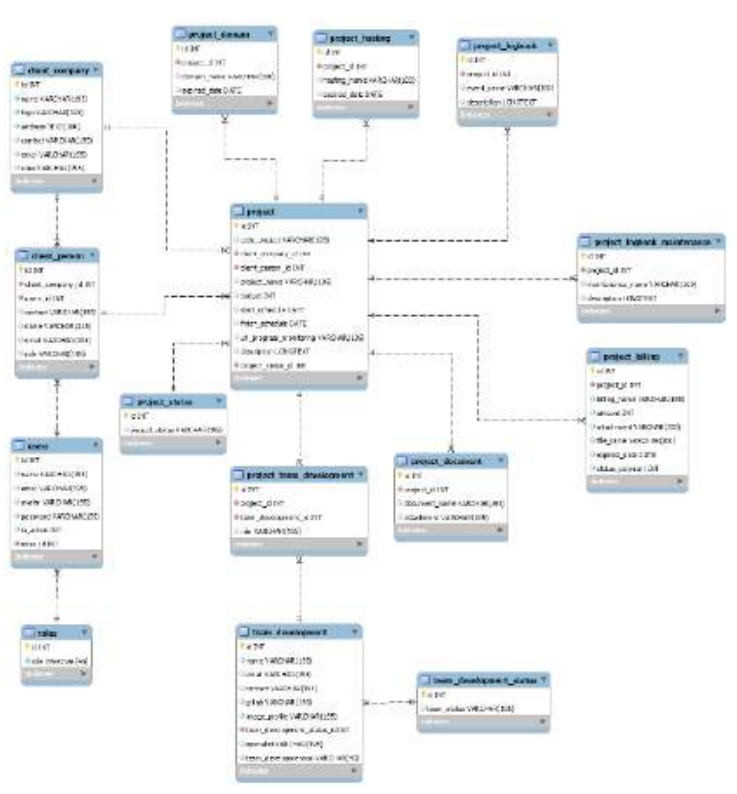

Gambar 2. Rancangan ERD Sistem

Setelah melakukan perancangan pada tahap Sprint Planning yang terdiri dari alur kerja sistem, rancangan basis data, serta konsep dari framework (kerangka kerja) yang akan digunakan, langkah selanjut nya atau langkah ke 4 dari tahapan pengembangan sistem ini adalah pembuatan Sprint. Pada tahap ini Backlog yang telah di definisikan sebelumnya akan ditentukan batas waktu penyelesaiannya. Yang mana pada kasus ini adalah selama proses magang berlangsung. Sehingga para tim pengembang dapat melihat dengan jelas proses apa yang harus dikerjakan, kapan waktu pengumpulannya, dan bagaimana status dari proses yang sedang dikerjakan tersebut. Berikut ini adalah Sprint dari sistem manajemen proyek yang akan dikembangkan penulis.

Tabel 3. Sprint

\begin{tabular}{|l|c|c|c|}
\hline Backlog Item & Start & Days & End \\
\hline Sprint & $\begin{array}{c}01 \text { Juni } \\
2021\end{array}$ & 40 & $\begin{array}{c}\text { 10 Juli } \\
2021\end{array}$ \\
\hline $\begin{array}{l}\text { Sistem dapat menampilkan data pada } \\
\text { Dashboard }\end{array}$ \\
\hline $\begin{array}{l}\text { Membedakan antara hak akses yang dimiliki } \\
\text { oleh admin dan Klien }\end{array}$ \\
\hline Sistem dapat menampilkan data Riwayat \\
\hline $\begin{array}{l}\text { Sistem dapat menampilkan data logbook } \\
\text { proyek } \\
\text { Sistem dapat menampilkan data Domain } \\
\text { proyek }\end{array}$ \\
\hline
\end{tabular}

\begin{tabular}{|c|}
\hline $\begin{array}{l}\text { Sistem dapat menampilkan data Hosting } \\
\text { proyek }\end{array}$ \\
\hline $\begin{array}{l}\text { Sistem dapat menc } \\
\text { proyek }\end{array}$ \\
\hline $\begin{array}{l}\text { Sistem dapat menampilkan data proses } \\
\text { Maintenance }\end{array}$ \\
\hline $\begin{array}{l}\text { Sistem dapat menampilkan data Billing } \\
\text { proyek }\end{array}$ \\
\hline $\begin{array}{l}\text { Sistem dapat menampilkan data Master untuk } \\
\text { admin }\end{array}$ \\
\hline Sistem dapat menampilkan data \\
\hline
\end{tabular}

Langkah yang lima / terakhir yang dilakukan adalah Review dan pengujian sistem. Sistem yang telah di implementasikan akan direview Kembali oleh penulis dan pihak perwakilan dari PT Santai Berkualitas Syberindo. Setelah melakukan evaluasi dan pengujian, maka sistem telah siap untuk digunakan.

\section{Proses Implementasi Sprint menjadi Sistem Website}

Berdasarkan Sprint tersebut, penulis mengembangkan sistem yang dibutuhkan berdasarkan Sprint yang telah dibuat.

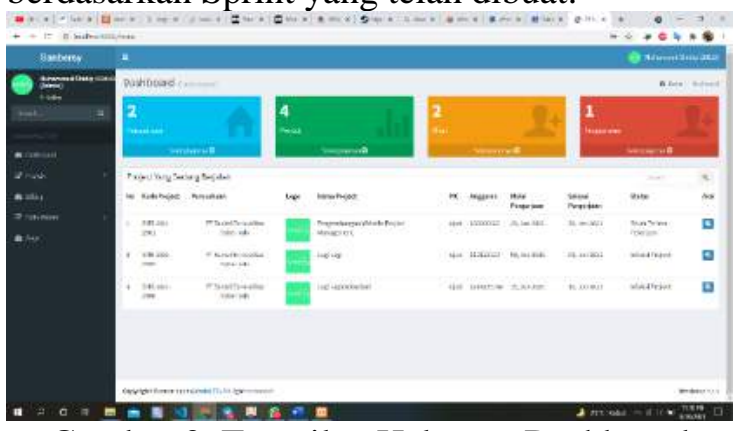

Gambar 3. Tampilan Halaman Dashboard

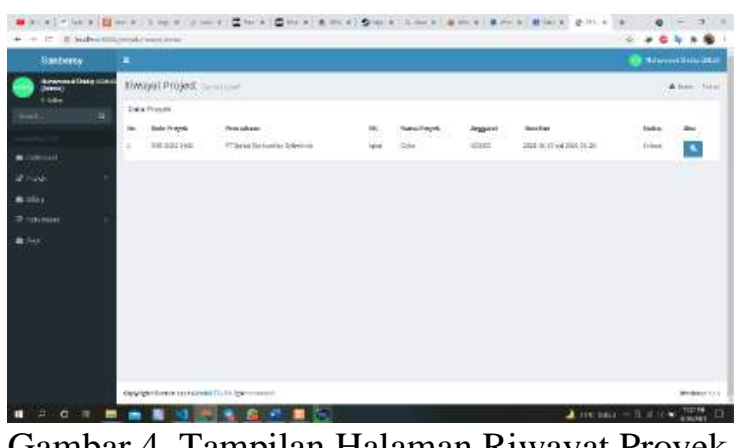

Gambar 4. Tampilan Halaman Riwayat Proyek 


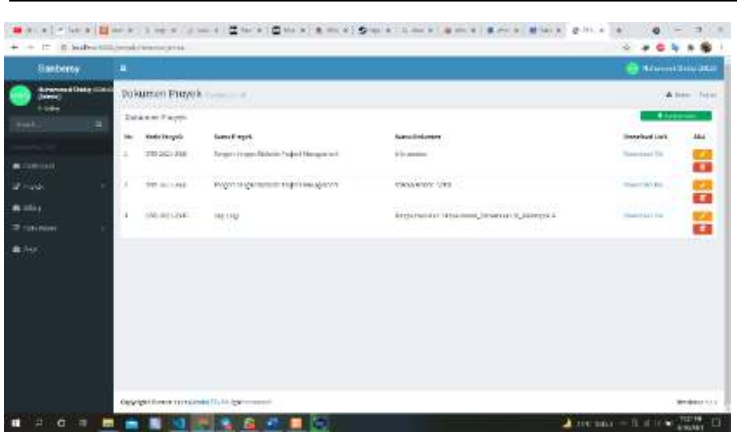

Gambar 5. Tampilan Halaman Dokumen

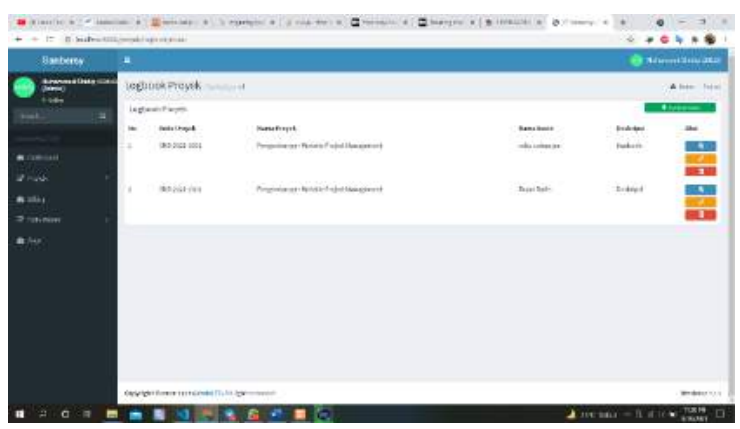

Gambar 6. Tampilan Halaman Logbook

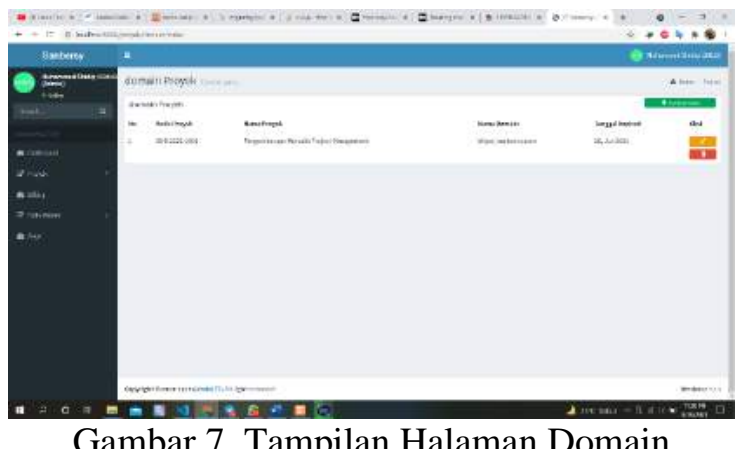

Gambar 7. Tampilan Halaman Domain

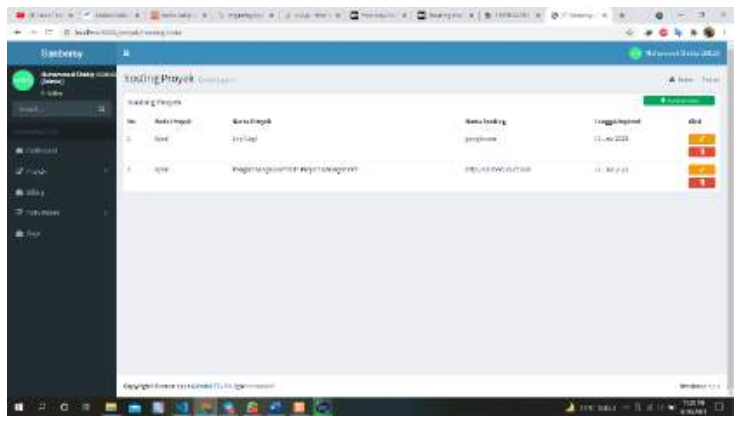

Gambar 8. Tampilan Halaman Hosting

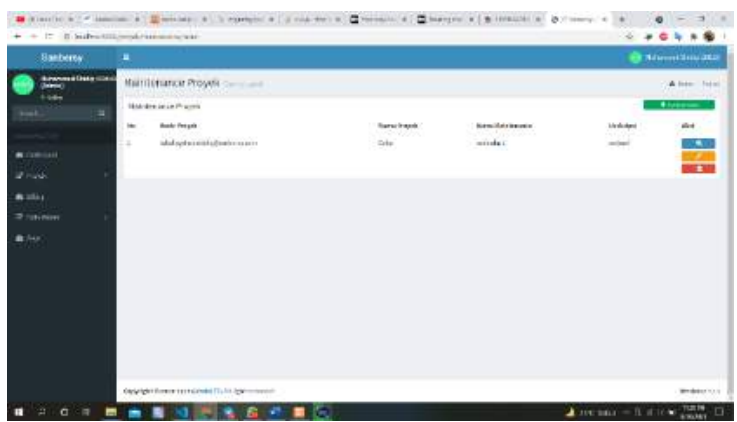

Gambar 9. Tampilan Halaman Maintenance

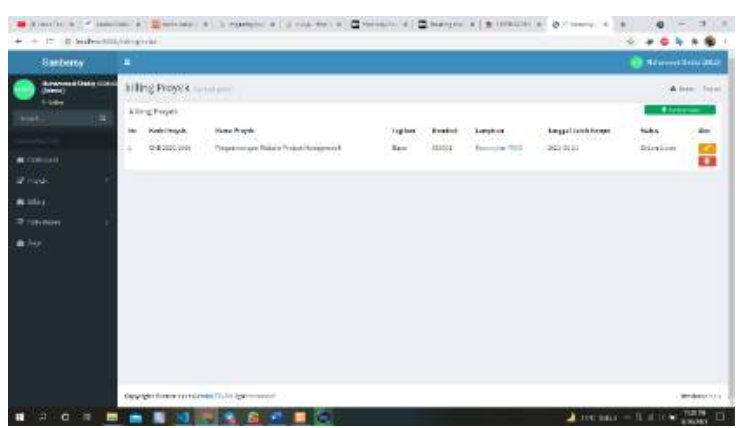

Gambar 10. Tampilan Halaman Billing

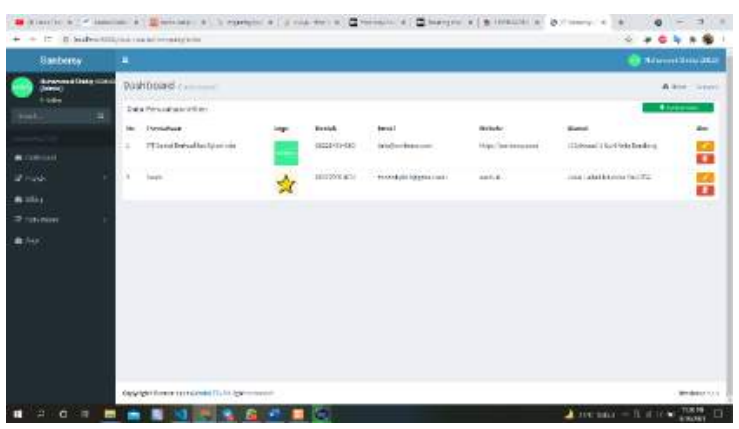

Gambar 11. Tampilan Halaman Data Perusahaan

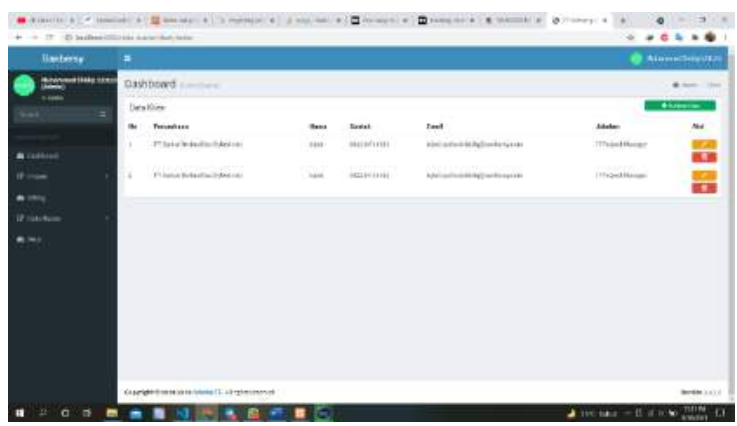

Gambar 12. Tampilan Halaman Data Klien

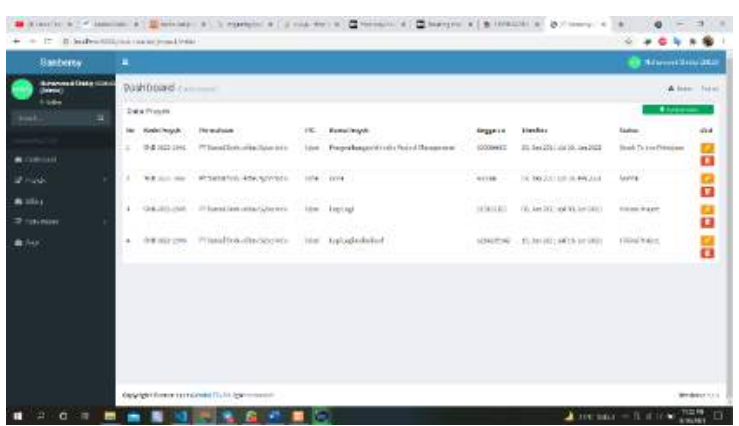

Gambar 13. Tampilan Halaman Proyek

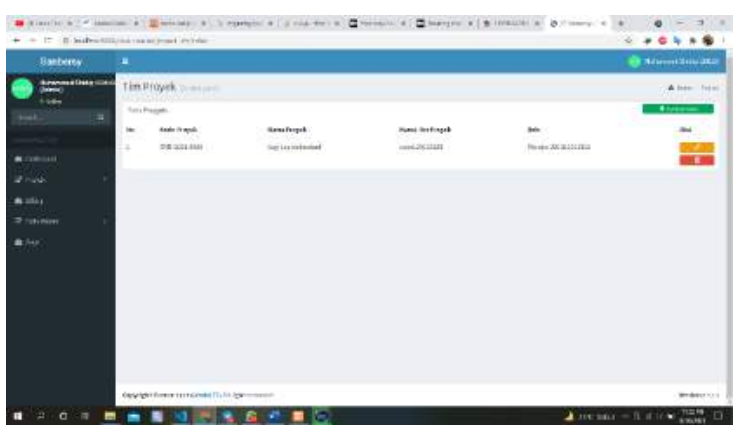

Gambar 14. Tampilan Halaman Tim Proyek 


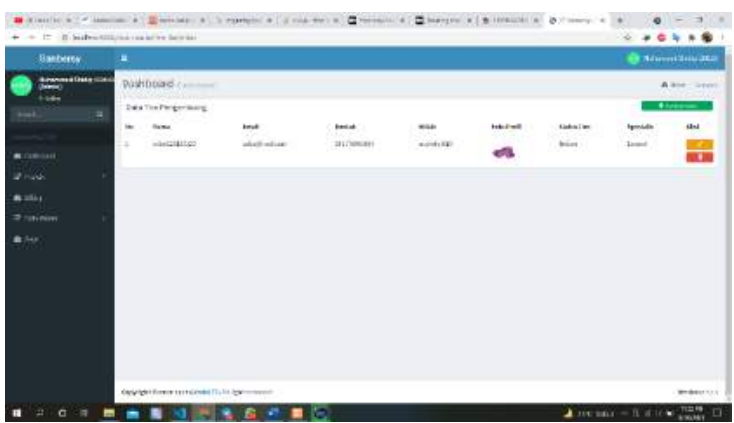

Gambar 15. Tampilan Halaman Tim Pengembang

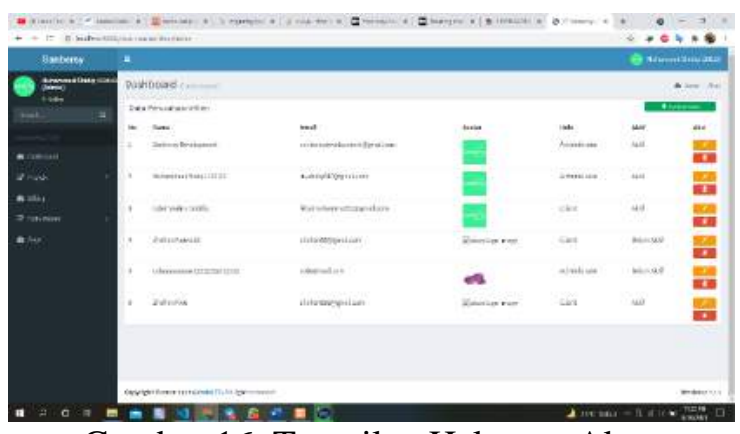

Gambar 16. Tampilan Halaman Akun

Setelah implementasi ini, maka akan dilakukan proses review dan pengujian sistem. Proses ini dilakukan oleh penulis dan perwakilan dari PT Santai Berkualitas Syberindo. Pengujian dilakukan agar dapat mengetahui kekurangan yang terdapat pada sistem. Setelah proses pengujian telah dilakukan, maka sistem telah siap untuk digunakan.

\section{Proses Implementasi Sprint menjadi Aplikasi}

Penulis juga mengimplementasikan sistem manajemen proyek ini menjadi sebuah rancangan aplikasi yang dapat di akses melalui smartphone. Berikut ini adalah lampiran mengenai rancangan aplikasi tersebut.

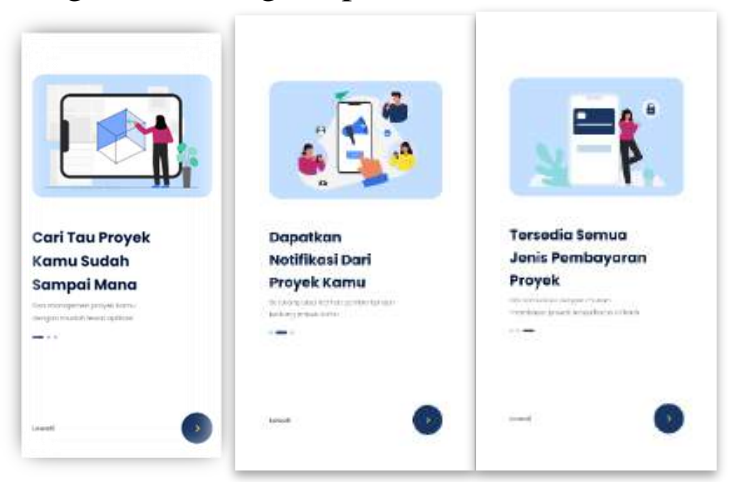

Gambar 17. Perancangan Desain Onboarding Screen

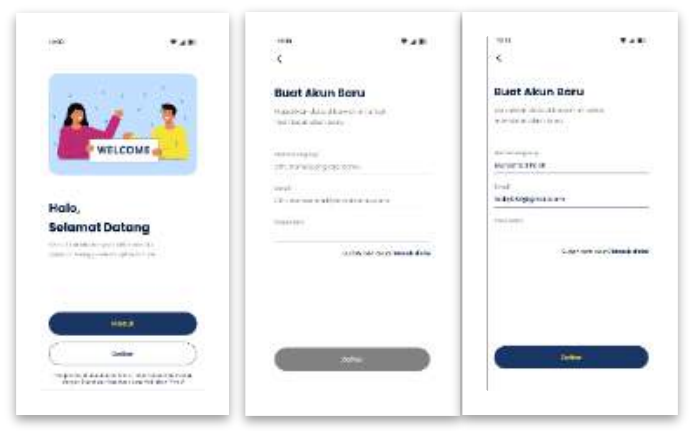

Gambar 18. Perancangan Register Screen

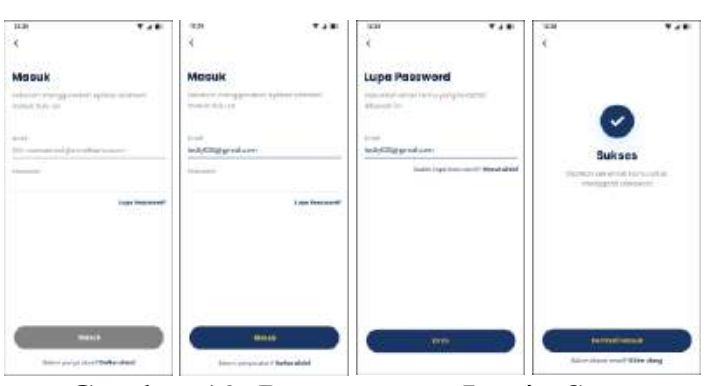

Gambar 19. Perancangan Login Screen

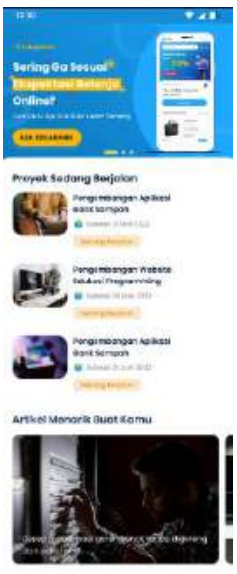

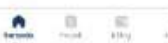

Gambar 20. Perancangan Home Screen

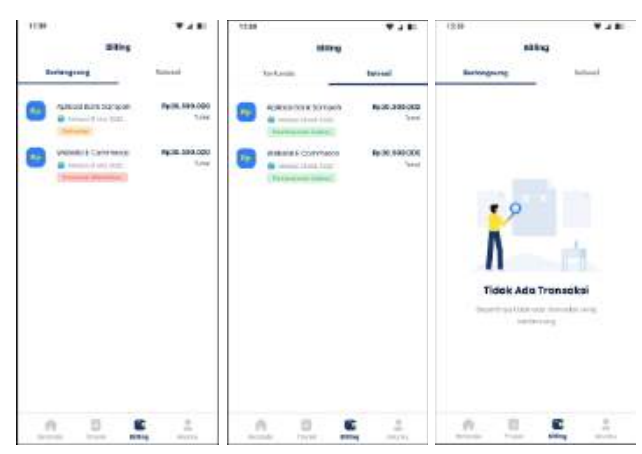

Gambar 21. Perancangan Billing Screen 


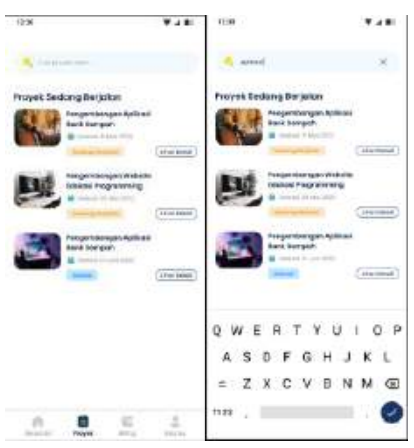

Gambar 22. Perancangan Project Screen

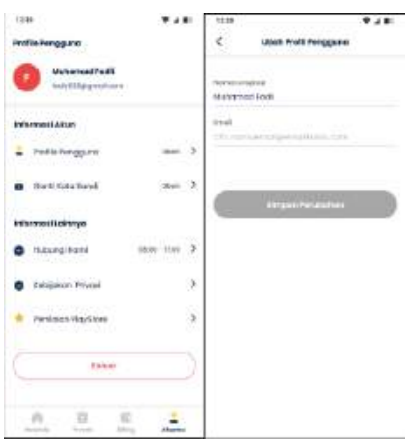

Gambar 23. Perancangan Account Screen

\section{KESIMPULAN}

Pada penelitian ini penulis menyimpulkan bahwasannya sistem manajemen proyek ini dapat membantu PT Santai Berkualitas Syberindo dalam memanajemen proyek proyek yang dimiliki. Dan penggunaan metode agile akan sangat berguna karena jika diperlukan sebuah fitur baru mengenai sistem tersebut. Maka tinggal membuat sebuah sprint baru untuk kemudian di implementasikan ke dalam sistem yang sedang berjalan.

\section{SARAN}

Kedepannya diharapkan penelitian ini dapat ditindaklanjuti, dikembangkan dan diimplikasikan. Karena seiring dengan perkembangan zaman, maka kebutuhan akan proyek proyek digital akan terus meningkat. Dan membutuhkan sebuah sistem yang dapat memanajemen proyek proyek tersebut dengan lebih efisien.

\section{UCAPAN TERIMA KASIH}

Pada kesempatan kali ini penulis ingin mengucapkan terima kasih kepada orang tua kami yang telah mendukung kegiatan yang dilakukan. Lalu penulis juga mengucapkan terima kasih kepada PT Santai Berkualitas Syberindo yang telah mengizinkan penulis untuk melakukan Kerja Praktik serta penelitian mengenai Sistem Manajemen Proyek.

\section{DAFTAR PUSTAKA}

[1] Edi Setiawan. 2019. Manajemen proyek Sistem Informasi Penggajian Berbasis Web. P-ISSN : 1693-6191 E-ISSN : 27157660

[2] Dewi Paramita. 2015. Rancang Bangun Sistem Informasi Kolaboratif Berbasis Web Untuk Manajemen Proyek Teknologi Informasi. Jurnal Buana Informatika, Volume 6, Nomor 3

[3] Ervianto, W.I. 2006. Teori Aplikasi Manajemen Proyek Konstruksi. Yogyakarta : Andi

[4] H. Syamsibar. 2021. Konsep Manajemen Agile; (Methodologi dalam Manajemen Proyek yang berfokus pada manusia, hasil, metode). ISSN: 2721-5407

[5] Fahrul Nurzaman. 2020. Pengembangan Sistem Otomatisasi Tagihan Menggunakan Metode Agile Software Development. Jurnal IKRA-ITH Informatika Vol 4 No 1

[6] Das, R., dan Saikia, L. P. (2016). Comparison of Procedural PHP with Codeigniter and Laravel Framework Title. International Journal of Current Trends in Engineering \& Research (IJCTER), 2(6), 42-48

[7] Schwaber, K., \& Jeff, S. (2013). Panduan Scrum TM 